International Journal of Engineering \& Technology, $7(4.38)(2018)$ 1358-1361
International Journal of Engineering \& Technology
SPC
Website: www.sciencepubco.com/index.php/IJET
Research paper

\title{
The Gap to Involve the Banking Cheques into Green Banking: Review and comparison about the contribution of Electronic Clearing Cheque System, Remote Cheque Deposit Service and Electronic Cheque Service in the Green Banking
}

\author{
Rawan Mowaffaq Ayed Madarmeh (Author) \\ Faculty of Technology \\ Asia Pacific University \\ Kuala Lampur, Malaysia \\ *Corresponding author E-mail: madarmeh@gmail.com
}

\begin{abstract}
Green banking is going to lead the banking sector into 21 st century, which is much needed in saving the world. The purpose of this paper is to address the gap in involving the banking cheques into green banking, by spotting the light on the environmental practices which are applied in Electronic Clearing Cheque System (ECCS), Remote Cheque Deposit Service (RCD) and Electronic Cheque Service (ECS) and the gaps in each. To achieve the purpose reviews and comparison in different aspects have been done which are related to ECCS, RCD and ECS. In addition, to guide the argument about the fact behind the death of paper cheques, especially after launching ECS which changed the direction of this argument. The findings could be used to help the banking in cheques field to go greener through focusing on investing in electronic cheque payment methods and improve the electronic cheque capabilities in the banking sector.
\end{abstract}

Keywords: Green Banking; Electronic Clearing Cheque System; Remote Cheque Deposit Service; Electronic Cheque Service; E-Cheque; E-Check

\section{Introduction}

The awareness in environmental issues requires the banks to involve themselves more in green banking, which is defined as "means of promoting environmentally friendly practices and reducing the carbon footprint from banking activities" [1-2]. Moreover, adopting the green banking bring various benefits to the banking sector [2]. Such as, achieving a sustainable growth, protecting the environment, and giving a positive image about the banks to their society [2].

The cheques represent one of the payment methods in the banking sector, a cheque is a certified document signed by the drawer and addressed to the bank/drawee requesting to pay a specific amount on their behalf to the beneficiary /payee or bearer on demand [3]. Various systems and services have been used in the banking sector to serve different stages in dealing with banking cheques. Such as Electronic Clearing Cheque System (ECCS), Remote Cheque Deposit Service (RCD) and The Electronic Cheque Service (ECS). However, each of them comes up with its own benefits and to take a step towards green banking.

\section{Methodology}

To address the gap to involve the banking cheques into green banking, two objectives were set: First, spotting the light on the environmental practices which are applied in ECCS, RCD and ECS and the gaps in each. Second: Guide the argument about the fact behind the death of paper cheques. To achieve the first objec- tive a set of secondary data as banking websites, literature reviews which are related to ECCS, RCD and ECS have been done, followed by a comparison between them in different perspectives. For achieving the second objective literature reviews as secondary data which are related to green banking and the argument about the death of paper cheques have been done. Finally, achieving the objectives leads to a set of recommendation which guides the banks and their clients in cheques banking field to get involved in green banking.

\section{Review About Electronic Clearing Cheque System, Remote Cheque Deposit Service and Electronic Cheque Service}
A. SYSTEM
REVIEW OF ELECTRONIC CHEQUES CLEARING
The mechanism of ECCS starts when the beneficiaries deposit the original cheques to their banks [4], Special scanners with MICR reader are used to take an electronic image for the paper cheque and its data [4]. The electronic image will be passed to the ECCS system for processing the electronic image of cheque instead of the real paper cheque [4]. In the central bank clearing centre, if there is any infraction in the electronic image, the electronic im- age will return to the beneficiary bank [4]. Otherwise, the elec- tronic image will be sent to the drawee bank [4]. The drawee in- spects the health of the data which is mentioned in the cheque [4], especially regarding the amount of the cheque and the signature of the drawer. After that, the drawee bank sends a response to the 
central bank clearing centre, whether positive or negative [4]. The clearing cemtre on its behalf will inform the beneficiary's bank about the response [4]. Jordan and Qatar are examples of countries which is using ECCS [5].

\section{B. REVIEW OF THE REMOTE CHEQUE DEPOSIT}

\section{SERVICE}

Some of the banks in different countries have served a cheque imaging deposit service remotely. This service enables the bank's customers to take a picture or scan for a signed physical original paper cheque, then send it to their banks, without any need to physically deliver the cheques to their banks [1][6-7]. The banks accept the digital images of the paper cheques and use them in clearing the cheques. USBANK and Bank of America are examples of these banks which is offering the mobile cheque deposit service through using smartphones [6-7]. In addition to many banks in USA offer the remote/mobile deposit cheques service, other countries have offered it such as RBC Royal bank in Canada [8], and Barclays bank in United Kingdom [9].

\section{REVIEW OF ELECTRONIC CHEQUES SERVICE}

The Hong Kong Monetary Authority HKMA launched the electronic cheques service on 7th December 2015 [10]. The electronic cheques are considered as an electronic document which is used for online transactions to substitute the paper cheque [11-12]. The E-Cheque is designed electronically to imitate the components of paper cheque design [12]. HKMA declared in the initial stage that nine banks offered E-Cheque issuance service which include Agricultural Bank of China, Bank of China /Hong Kong, Chiyu Banking Corporation, Fubon Bank /Hong Kong, Hang Seng Bank, Nanyang Commercial Bank, The Bank of East Asia, The Hong Kong and Shanghai Banking Corporation and Wing Lung Bank [10]. The issuance of E-Cheque is required from the clients to log in to their internet banking account, then select E-Cheque issuance service [11-12]. After that they have to input the payee name, cheque date and cheque amount in figures, then the E-Cheque will be generated by the bank with the digital signature [12]. Finally, the E-Cheque needs to download and send it to the payee through email in PDF format [11-12]. Depositing of E-Cheque requires from clients to log in to their internet banking account, then select E-Cheque deposit service [11-12]. After that they have to choose the deposit account then upload the E-Cheques which they have received [11-12].

\section{THE ARGUMENT ABOUT THE DEATH OF PAPER CHEQUES}

In 2014, the argument about the death of paper cheque was considered as a kind of an exaggeration [3] [16]. First, due to many reasons Vines et al., (2012) mentioned that use of cheques represents a flexible banking payment method in such a way that electronic payments do not offer [16]. Second, the provisions which are made to limit the physical delivery of the cheques by relying on the cheques image as a replacement of original paper cheque document [3], that is exactly what is happening in RCD and ECCS, but not in ECS, which is a paperless cheque service that uses an electronic cheque not a scanned or electronic image of paper cheques. Hence, ECS was launched on 7th of December 2015 [10], the argument took a new direction after it, as ECS is considered as the first electronic cheque banking service which offers requesting, issuing and depositing service using electronic banking cheques without the existence of the physical paper as evidence.

\section{Comparison Between the Electronic Cheques Clearing System, Remote Deposit Service and Electronic Cheques Service}

\begin{tabular}{|c|c|c|c|}
\hline $\begin{array}{c}\text { The aspects of } \\
\text { comparison }\end{array}$ & ECCS & RCD & ECS \\
\hline $\begin{array}{c}\text { The purpose of } \\
\text { the sys- } \\
\text { tem/service }\end{array}$ & $\begin{array}{c}\text { Clearing the } \\
\text { paper cheques }\end{array}$ & $\begin{array}{c}\text { Remotely de- } \\
\text { positing of } \\
\text { paper cheques }\end{array}$ & $\begin{array}{c}\text { Requesting, } \\
\text { issuing and } \\
\text { depositing }\end{array}$ \\
\hline
\end{tabular}

\begin{tabular}{|c|c|c|c|}
\hline & & & $\begin{array}{l}\text { electronic } \\
\text { cheques }\end{array}$ \\
\hline $\begin{array}{l}\text { Technique of } \\
\text { the cheque } \\
\text { transmission }\end{array}$ & $\begin{array}{l}\text { Electronic im- } \\
\text { age of } \\
\text { scanned paper } \\
\text { cheque }\end{array}$ & $\begin{array}{c}\text { Electronic } \\
\text { image of pa- } \\
\text { per cheque }\end{array}$ & $\begin{array}{l}\text { Electronic } \\
\text { cheque itself }\end{array}$ \\
\hline $\begin{array}{l}\text { Existence of } \\
\text { the paper } \\
\text { cheque }\end{array}$ & $\begin{array}{l}\text { There is a } \\
\text { physical exist- } \\
\text { ence of the pa- } \\
\text { per cheque }\end{array}$ & $\begin{array}{c}\text { There is a } \\
\text { physical ex- } \\
\text { istence of the } \\
\text { paper cheque }\end{array}$ & $\begin{array}{c}\text { Paperless } \\
\text { service, no } \\
\text { use of physi- } \\
\text { cal paper } \\
\text { cheques. }\end{array}$ \\
\hline $\begin{array}{c}\text { Time and place } \\
\text { of depositing }\end{array}$ & $\begin{array}{c}\text { Via banks } \\
\text { branches dur- } \\
\text { ing the banks } \\
\text { working days, } \\
\text { in the specific } \\
\text { bank working } \\
\text { hours. }\end{array}$ & $\begin{array}{c}\text { Any time of } \\
\text { any day, an- } \\
\text { ywhere. }\end{array}$ & $\begin{array}{l}\text { Any time of } \\
\text { any day, an- } \\
\text { ywhere. }\end{array}$ \\
\hline Statistical study & $\begin{array}{l}\text { "A study by } \\
\text { electronic } \\
\text { Cheque clear- } \\
\text { ing house or- } \\
\text { ganization } \\
\text { (ECCHO) } \\
\text { found that the } \\
\text { banks with (10) } \\
\text { billion dollars } \\
\text { assets, will } \\
\text { save (7) million } \\
\text { dollars as a re- } \\
\text { sult of clearing } \\
\text { the cheque } \\
\text { electronically, } \\
\text { and banks with } \\
\text { (1000) billion } \\
\text { dollars will } \\
\text { save (260) mil- } \\
\text { lion dollar per } \\
\text { year" [13]. }\end{array}$ & $\begin{array}{c}\text { US bank Red- } \\
\text { stone Credit } \\
\text { Union has en- } \\
\text { abled to save } \\
90 \% \text { of the } \\
\text { cost for pro- } \\
\text { cessing each } \\
\text { cheque by of- } \\
\text { fering the } \\
\text { mobile depos- } \\
\text { it transaction } \\
\text { [14]. This has } \\
\text { minimized the } \\
\text { cost of a } \\
\text { branch trans- } \\
\text { action from } \\
\$ 4.00 \text { to } \$ 0.40 \\
\text { for each } \\
\text { cheque [14]. }\end{array}$ & $\begin{array}{c}\text { Chief Execu- } \\
\text { tive in } \\
\text { Hong Kong } \\
\text { Monetary } \\
\text { Authority, } \\
\text { Norman Chan } \\
\text { mentioned } \\
\text { that "If half } \\
\text { of the paper } \\
\text { cheques are } \\
\text { replaced by } \\
\text { E-Cheque, } \\
\text { we save } 18 \\
\text { million sheets } \\
\text { of paper or } \\
1,800 \text { trees, } \\
\text { which in turn } \\
\text { reduce } 130 \\
\text { tonnes of } \\
\text { carbon diox- } \\
\text { ide emission } \\
\text { every year } \\
\text { (equivalent to } \\
\text { the size of } 28 \\
\text { standard } \\
\text { swimming } \\
\text { pools)." }[15]\end{array}$ \\
\hline $\begin{array}{c}\text { Additional Ad- } \\
\text { vantages }\end{array}$ & $\begin{array}{l}\text { Saving the con- } \\
\text { sumed time, } \\
\text { money and efforts } \\
\text { between the dif- } \\
\text { ferent banks side, } \\
\text { which are in- } \\
\text { volved in cheques } \\
\text { clearing. }\end{array}$ & $\begin{array}{c}\text { Saving the } \\
\text { consumed } \\
\text { time, money } \\
\text { and effort } \\
\text { from both } \\
\text { sides, banks' } \\
\text { employees } \\
\text { and payees, } \\
\text { which are in- } \\
\text { volved to } \\
\text { complete the } \\
\text { depositing } \\
\text { transaction of } \\
\text { a physical pa- } \\
\text { per cheque. }\end{array}$ & $\begin{array}{l}\text { Saving the } \\
\text { consumed } \\
\text { time, money } \\
\text { and effort } \\
\text { from both } \\
\text { sides, banks } \\
\text { and banks' } \\
\text { clients in- } \\
\text { cluding pay- } \\
\text { ees and } \\
\text { drawers, } \\
\text { which are in- } \\
\text { volved in re- } \\
\text { questing, is- } \\
\text { suing and de- } \\
\text { positing } \\
\text { transactions. }\end{array}$ \\
\hline
\end{tabular}




\section{Environmental Practices Which Are Ap- plied in Eccs, Red And Ecs And The Gaps In Each.}

\begin{tabular}{|c|c|c|c|c|}
\hline $\begin{array}{c}\text { Name } \\
\text { of Ser- } \\
\text { vice/ } \\
\text { System }\end{array}$ & $\begin{array}{c}\text { Activity } \\
\text { Type and } \\
\text { Environment } \\
\text { Mode }\end{array}$ & $\begin{array}{l}\text { The Environ- } \\
\text { mental Prac- } \\
\text { tices }\end{array}$ & $\begin{array}{l}\text { The Posi- } \\
\text { tive Effect } \\
\text { of Activity }\end{array}$ & $\begin{array}{c}\text { Gap in } \\
\text { Practices } \\
\text { to Involve } \\
\text { into Green } \\
\text { Banking }\end{array}$ \\
\hline ECCS & $\begin{array}{l}\text { Activity type: } \\
\text { Clearing. } \\
\text { Mixed paper/ } \\
\text { electronic } \\
\text { scanned } \\
\text { cheques } \\
\text { environment. }\end{array}$ & $\begin{array}{l}\text { ECCS over- } \\
\text { steps the physi- } \\
\text { cal movement } \\
\text { of paper } \\
\text { cheques be- } \\
\text { tween payee } \\
\text { bank, drawee } \\
\text { bank } \\
\text { and clearing } \\
\text { house by using } \\
\text { the scanned } \\
\text { electronic } \\
\text { image of paper } \\
\text { cheques instead } \\
\text { of moving the } \\
\text { original paper } \\
\text { cheques. }\end{array}$ & $\begin{array}{l}\text { Minimize } \\
\text { the air } \\
\text { pollution } \\
\text { caused by } \\
\text { using } \\
\text { vehicles to } \\
\text { move the } \\
\text { paper } \\
\text { cheques } \\
\text { between } \\
\text { different } \\
\text { parties for } \\
\text { clearing. }\end{array}$ & $\begin{array}{c}\text { ECCS } \\
\text { serves just } \\
\text { the clearing } \\
\text { operation } \\
\text { of banking } \\
\text { cheques. } \\
\text { ECCS } \\
\text { keeps } \\
\text { paper } \\
\text { cheque } \\
\text { which is } \\
\text { considered } \\
\text { as a source } \\
\text { of the } \\
\text { scanned } \\
\text { electronic } \\
\text { cheque } \\
\text { image. }\end{array}$ \\
\hline RCD & $\begin{array}{l}\text { Activity type: } \\
\text { Depositing. } \\
\text { Mixed paper/ } \\
\text { electronic } \\
\text { image } \\
\text { cheques } \\
\text { environment. }\end{array}$ & $\begin{array}{l}\text { RCD oversteps } \\
\text { the physical } \\
\text { delivery of } \\
\text { paper cheques } \\
\text { when payees } \\
\text { visit banks to } \\
\text { deposit the } \\
\text { paper cheques, } \\
\text { the banks ac- } \\
\text { cept the digital } \\
\text { images of the } \\
\text { paper cheques } \\
\text { and use them in } \\
\text { clearing. }\end{array}$ & $\begin{array}{l}\text { Minimize } \\
\text { the air } \\
\text { pollution } \\
\text { caused by } \\
\text { vehicles } \\
\text { when } \\
\text { payees use } \\
\text { them to } \\
\text { visit } \\
\text { banks. }\end{array}$ & $\begin{array}{c}\text { RCD } \\
\text { serves just } \\
\text { the } \\
\text { depositing } \\
\text { operation } \\
\text { of banking } \\
\text { cheques. } \\
\text { Keeps the } \\
\text { paper } \\
\text { cheque as a } \\
\text { source of } \\
\text { the } \\
\text { electronic } \\
\text { cheque } \\
\text { image. }\end{array}$ \\
\hline ECS & $\begin{array}{l}\text { Activity type: } \\
\text { Requesting, } \\
\text { issuing and } \\
\text { depositing. } \\
\text { Electronic / } \\
\text { paperless } \\
\text { cheques } \\
\text { environment. }\end{array}$ & $\begin{array}{l}\text { ECS ends the } \\
\text { physical } \\
\text { existence } \\
\text { of paper } \\
\text { cheques and the } \\
\text { need of cheque } \\
\text { book. }\end{array}$ & $\begin{array}{l}\text { Fully } \\
\text { paperless } \\
\text { Cheque } \\
\text { service } \\
\text { which } \\
\text { helps to } \\
\text { save the } \\
\text { trees. } \\
\text { Minimize } \\
\text { the air } \\
\text { pollution } \\
\text { caused by } \\
\text { frequent } \\
\text { visit of } \\
\text { payees and } \\
\text { drawers to } \\
\text { banks, as a } \\
\text { result of } \\
\text { using } \\
\text { electronic } \\
\text { channels } \\
\text { to deliver } \\
\text { and } \\
\text { receive the } \\
\text { electronic } \\
\text { cheques. }\end{array}$ & $\begin{array}{c}\text { ECS serves } \\
\text { requesting, } \\
\text { issuing and } \\
\text { depositing } \\
\text { of } \\
\text { electronic } \\
\text { banking } \\
\text { cheques } \\
\text { only. } \\
\text { ECS has } \\
\text { been } \\
\text { applied } \\
\text { under some } \\
\text { constraints, } \\
\text { the } \\
\text { electronic } \\
\text { cheque in } \\
\text { ECS is not } \\
\text { negotiable } \\
\text { or } \\
\text { transferable } \\
\text { as well as it } \\
\text { is not } \\
\text { allowed to } \\
\text { cash it } \\
\text { [12]. }\end{array}$ \\
\hline
\end{tabular}

\section{Conclusion}

The following conclusion is drawn from the previous reviews, comparison and the previous argument. First, due to the electronic/ paperless cheque which has been experienced in banking sector in Hong Kong since 2015 [10], this experience creates the possibility of shifting the paper cheque users to electronic/ paperless cheque payment method by using electronic version of banking cheques, hence the argument mentioned that use of paper cheques represents a flexible payment banking method in such a way that electronic payments do not [16]. This will guide the banks to take care of offering electronic banking cheques services in such a way to keep the flexibility which clients find in paper cheques. This will lead to suggest on how to make the use of the electronic cheque as flexible as the use of the paper cheque as a banking payment method that makes it efficient. Second, to encourage the paper cheque client to shift into an electronic paperless cheque payment method, some additional advantages from using the electronic channel should be gained by the clients, for example archiving capabilities of electronic cheque details, and solving some problems which paper cheque users may face while using the physical paper cheque. Third, according to the environmental practices which are applied in ECCS, RCD and ECS the continuous development in the electronic cheque banking services have involved banks and their clients into green banking by minimizing the air pollution, in addition ECS ends successfully the consumption of paper cheques in its service. Fourth, banks around the world should invest more in the electronic cheque and improve its capabilities to let banking cheque field go greener.

\section{References}

[1] Manohar, B. \& Kumar, C. H. V. (2012) Green Banking: "bye-bye cheques, hello electronic payments". Asia Pacific Journal of Management \& Entrepreneurship Research. [online] 1(3). P. 60-74. Available from: http://search.proquest.com.ezproxy.apiit.edu.my/docview/13176171 66? accountid=46052. [Accessed: 1 october 2017].

[2] Kaur, G. (2016) Green initiatives of banks in India: A paradigm shift. Journal of Commerce and Management Thought. [online] 7(3). P. 488-500. Available from: http://search.proquest.com.ezproxy.apiit.edu.my/docview/18027515 13/abstract/24BEE7906459461APQ/1 ?accountid=46052. [Accessed: 8 October 2017].

[3] Geva, B. (2014) Is the death of the paper cheque upon us? the electronic presentment and deposit of cheques in Canada. Banking \& Finance Law Review. [online] 30(1). P. 113-125. Available from: http://search.proquest.com.ezproxy.apiit.edu.my/docview/16285576 18? accountid=46052. [Accessed: 9 October 2017].

[4] Leshhib, A. \& Melhem, B. (2013) The legal regulation of electronic clearing of cheques and legal relations arising therefrom in the Jordanian low. Dirasat: Ulum al-Shariah wa-al-Qanun.[online] 40 (2) .P $\quad .456-473 . \quad$ Available from: https://journals.ju.edu.jo/DirasatLaw/article/viewFile/5430/3460. [Accessed: 18 October 2017].

[5] AL-Refai, M. F. \&Nawafleh S. A. (2014) The Impact of Introducing the Electronic Cheques Clearing (ECC) on the Value of Cheques Presented for Clearing and Returned Cheques in Jordan. International Journal of Business and Management. [Online] 9 (4). P. 182-190. Available from: http://citeseerx.ist.psu.edu/viewdoc/download?doi=10.1.1.846.6082 \&rep=rep1\&type=pdf. [Accessed: 2 October 2017].

[6] USBANK (2016) Mobile check deposit with DepositPoint [online]Available from: https://www.usbank.com/mobile/depositpoint.html. [Accessed: 12 October 2017].

[7] BANK OF AMERICA (2016) Deposit checks easily with Mobile Check Deposit. [online] Available from: http://promo.bankofamerica.com/mobile-check-deposit/. [Accessed: 15 October 2017].

[8] RBC ROYAL BANK (2016) Mobile Cheque Deposit. [online]Available http://www.rbcroyalbank.com/mobile/cheque-deposit.html [Ac- 
cessed: 16 October 2017].

[9] BARCLAYS (2016) Try a new way to pay in cheques with your phone. [online]

Available from http://www.barclays.co.uk/MobileBankingservices/FutureOfChequ es/P1242668989519. [Accessed: 1 October 2017].

[10] Hong Kong monetary authority (2015a) Launch of electronic cheque publicity campaign. [online]. Available from: http://www.hkma.gov.hk/eng/key-information/pressreleases/2015/20151123-3.shtml. [Accessed: 12 October 2017].

[11] Hong Kong monetary authority (2015b) Retail Payment Development. [online]. Available from: http://www.hkma.gov.hk/eng/keyfunctions/international-financial-centre/infrastructure/retailpayment-development.shtml. [Accessed: 12 October 2017].

[12] Hong Kong monetary authority (2015c) Electronic cheque EBrochure.

[online]. Available from: http://www.hkma.gov.hk/media/eng/doc/keyfunctions/finanical-infrastructure/infrastructure/retail-paymentinitiatives/e-Cheque_e-brochure_Plain_Text_eng.pdf. [Accessed: 13 October 2017].

[13] Alshibly, H.H. (2011) An extended Tam Model to evaluate user's acceptance of electronic cheque clearing systems at Jordanian Commercial Banks. Australian Journal of Basic and Applied Sciences. [online] 5(5). P.147-156. Available from: http://ajbasweb.com/old/ajbas/2011/147-156.pdf [Accessed: 15 October 2017].

[14] COMPUTER WEEKLY, Saran, C. (2014) UK set to establish digital cheques in 2015. [online] Available from: http://www.computerweekly.com/news/2240235484/UK-set-toestablish-digital-cheques-in-2015. [Accessed: 22 October 2017].

[15] Hong Kong monetary authority (2015d) E-Cheque: A new era of payments in Hong Kong. [online]. Available from: http://www.hkma.gov.hk/eng/key-

information/insight/20151029.shtml. [Accessed: 26 October 2017].

[16] Vines, J., Dunphy, P., Blythe, M., Lindsay, S., Monk, A. \& Olivier, P. (2012) The joy of cheques: trust, paper and eighty somethings. Proceedings of the ACM 2012 conference on Computer Supported Cooperative Work. Washington, 11th February to 15th February 2012. New York: ACM. pp. 147-156. 